\title{
HBV AND HCV SEROLOGICAL MARKERS IN PATIENTS WITH THE HEPATOSPLENIC FORM OF MANSONIC SCHISTOSOMIASIS
}

\author{
Jéfferson Luis de Almeida SILVA', Veridiana Sales Barbosa de SOUZA ${ }^{1}$, \\ Tatiana Aguiar Santos VILELLA ${ }^{1}$, Ana Lúcia C. DOMINGUES ${ }^{2}$ and \\ Maria Rosângela Cunha Duarte COẾLHO', 3
}

\begin{abstract}
Context - Blood transfusion is one of the major risk factors for the transmission of the hepatitis B (HBV) and C (HCV) viruses. However, there are no reports describing the endoscopic transmission of these viruses in patients with the hepatosplenic form of schistosomiasis. Objective - To estimate the prevalence of serological markers of HBV and HCV in patients with the hepatosplenic form of schistosomiasis and evaluate the possible risk factors associated with these infections. Methods - A cross-sectional study was conducted on 230 patients with hepatosplenic form of schistosomiasis who attended a university hospital in Recife, Northeastern Brazil, from February to August 2008. The patients answered a standardized questionnaire about risk factors. Serum samples were analyzed for anti-HBc total, anti-HBs, HBsAg, and anti-HCV using enzyme-linked immunosorbent assays. Univariate analysis and multiple logistic regression were performed. Results - The prevalence was 30\% for anti-HBc total and/or HBsAg and 7.4\% for anti$\mathrm{HCV}$. There was a higher frequency of the serological markers in females and in patients aged $\geq 50$ years. A significant association was detected between the presence of anti-HCV and the receipt of six or more blood transfusions. There was no association of history and number of digestive endoscopies with the serological markers analyzed. Conclusions - We observed a higher prevalence of serological markers for HBV and a lower prevalence of anti-HCV. Our results indicate that females and patients of an advanced age are the most affected categories and that patients that received multiple transfusions are at a higher probability of HCV infection. HEADINGS - Biological markers. Hepatitis B. Hepatitis C. Schistosomiasis mansoni.
\end{abstract}

\section{INTRODUCTION}

Schistosomiasis remains one of the most prevalent parasitic infections in Brazil, which is considered one of the largest endemic foci of Schistosoma mansoni, and it is estimated that 6 to 8 million Brazilians are infected and 30 million are at risk of infection ${ }^{(24)}$.

In the Northeast of Brazil, especially in Pernambuco, Alagoas, and Bahia states, the highest prevalence of chronic mansonic schistosomiasis is observed, with more than $90 \%$ of patients presenting the mild form and $4 \%-10 \%$ presenting the severe form of the disease, denominated hepatosplenic ${ }^{(17)}$.

Studies point to the worsening of the clinical state of schistosomiasis due to infection with viral hepatitis because of the increased frequency of jaundice, ascites and liver failure. Additionally, there is an increase in viral persistence and the liver fibrosis develops more quickly ${ }^{(13,31)}$. All of these factors contribute to the development of aggressive chronic liver disease.

Egypt has the highest worldwide prevalence for the concomitant infection of schistosomiasis and viral hepatitis, where the rates vary from 19.6\%-64\% for the hepatitis B virus (HBV) and 10.3\%-67\% for the hepatitis $\mathrm{C}$ virus $(\mathrm{HCV})^{(1,10)}$.

In Brazil, concomitant infection has a lower prevalence; however, higher rates are observed in patients from hospitals, varying from $10.2 \%-15.8 \%$ for $\mathrm{HBV}$ and $0.5 \%-19.66 \%$ for $\mathrm{HCV}^{(2,7,23)}$.

In Pernambuco, a higher frequency of serological markers of these hepatitis was observed in patients with the hepatosplenic form of schistosomiasis (HSS), varying from $13.6 \%-40 \%$ for $\mathrm{HBV}$ and $11.9 \%-20 \%$ for $\operatorname{HCV}^{(18,19,30)}$.

Blood transfusions in patients with HSS, carried out due to episodes of upper gastrointestinal bleeding, represent a important risk factor for the transmission

\footnotetext{
Places of research achievement: Gastroenterology Outpatient Clinic at the Clinics Hospital and Division of Virology at Laboratory of Immunopathology Keizo Asami, both at Federal University of Pernambuco, Recife, PE, Brasil.

Funding: FINEP/CT - SAÚDE (1455/03)

Conflicts of interest: none declared

${ }^{1}$ Laboratory of Immunopathology Keizo Asami (LIKA). Federal University of Pernambuco (UFPE); ${ }^{2}$ Departament of Clinical Medicine UFPE; ${ }^{3}$ Departament of Physiology and Pharmacology UFPE, Recife, PE, Brasil.

Correspondence: Dr. Maria Rosângela Cunha Duarte Coêlho - Rua Manuel Lubambo, 118 - Afogados - 50850-040 - Recife, PE, Brasil. E-mail: rcoelholika@gmail.com
} 
of $\mathrm{HBV}$ and $\mathrm{HCV}^{(28)}$. Reports of probable interpersonal transmission of $\mathrm{HBV}$ and $\mathrm{HCV}$ through digestive endoscopy raised concerns regarding the endoscopic procedures ${ }^{(6,8)}$. Since patients with HSS often undergo periodic upper endoscopy for the evaluation and treatment of esophageal varices, this intervention may be a risk factor for the transmission of these viruses.

Given the clinical relevance of schistosomiasis, especially in the Northeast of Brazil where its prevalence is high, the objective of this study was to estimate the frequency of HBV and HCV serological markers in patients with HSS and to evaluate the possible risk factors associated with these infections.

\section{METHODS}

\section{Study site and patient selection}

We enrolled patients who attended the Gastroenterology Outpatient Clinic at the Clinics Hospital, Federal University of Pernambuco, Recife, PE, Brazil, from February to August 2008. The study included patients of both genders who were diagnosed with HSS, confirmed by the clinical history of the patients (contact with water from a Schistosoma mansoni endemic area or with a history of treatment for schistosomiasis) and the presence of hepatosplenomegaly in a physical examination, combined with evidence of portal hypertension and periportal fibrosis (Symmers' fibrosis) by ultrasound or a previous splenectomy.

It was excluded patients presenting with symptoms of other liver diseases and those with other clinical forms of schistosomiasis. From the 238 invited patients, 8 refused to participate and the remaining 230 patients signed an informed consent statement.

This cross-sectional study was approved by the Ethics Committee of Research from the Health Sciences Center, Federal University of Pernambuco, Brazil (research protocol number: 373/07).

\section{Data collection}

Through a standardized questionnaire, data were collected from each patient, including gender, age and the following potential risk factors for the transmission of $\mathrm{HBV}$ and $\mathrm{HCV}$ : history, period (before or after 1993) and number of blood transfusions, history and number of digestive endoscopies, history of sclerotherapy or elastic ligation of esophageal varices, history of surgery, history of splenectomy, history of dental treatment, presence of tattoos/piercing, history of intravenous drug use, frequency of male condom use and history of intercourse with other men.

\section{Collection of blood samples and serology for the hepatitis $B$ and $C$ viruses}

It was collected $10 \mathrm{~mL}$ of blood by venipuncture from each patient using tubes without anticoagulant. Sera were obtained by centrifugation of blood and stored at $-20^{\circ} \mathrm{C}$ until the serologic tests were performed.
Serological markers for $\mathrm{HBV}$ and $\mathrm{HCV}$ were investigated using commercially available enzyme-linked immunosorbent assays according to the manufacturer's instructions.

All samples were tested for anti-HBc total (Monolisa Anti-HBc Total Plus; Bio-Rad Laboratories, France) and anti-HBs (anti-HBs Monolisa Plus; Bio-Rad Laboratories, France). Only the samples reactive for anti-HBc total and non-reactive for anti-HBs were tested for $\mathrm{HBsAg}$ (HBsAg Hepatitis B; Wiener Lab, Argentina). The presence of anti$\mathrm{HCV}$ was investigated using the Hepatitis $\mathrm{C}$ anti-HCV (Wiener Lab, Argentina).

\section{Statistical analysis}

Data from each patient were analyzed using the Epi Info program version 6.04, where tests of association between the positivity of serological markers and each variable of the study were verified using the prevalence ratio (PR) and the $95 \%$ confidence interval $(95 \% \mathrm{CI})$.

The chi-square $\left(\chi^{2}\right)$ and Fischer's exact test were used, when appropriate, to determine whether the associations were statistically significant. Statistical significance was considered for $P$-values $<0.05$. In order to monitor the confusion effect, all of these associations were adjusted for age.

The variables that showed a significance probability less than $20 \%(P<0.20)$ in univariate analysis were analyzed using the multiple logistic regression type forward in SPSS for Windows v. 11.0.1.

\section{RESULTS}

Among the analysed patients, $58.7 \%(135 / 230)$ were females and the mean age was $55 \pm 12.6$ years. In respect to the age group distribution, $71.7 \%(165 / 230)$ were $\geq 50$ years.

The prevalence of serological markers of $\mathrm{HBV}$ was $30 \%$ (69/230), considering the positivity of anti-HBc total and/or HBsAg. We emphasize that $66.5 \%$ of patients showed no viral markers and were considered susceptible to HBV infection. The anti-HBs alone was found in $3.5 \%$ of patients (Table 1 ), whereas the prevalence of anti-HCV was $7.4 \%(17 / 230)$.

TABLE1. Prevalence of serological markers for HBV in patients with the hepatosplenic form of schistosomiasis

\begin{tabular}{lcc}
\hline \multirow{2}{*}{ Serological markers } & \multicolumn{2}{c}{ Positivity } \\
\cline { 2 - 3 } & Frequency & $\%$ \\
\hline Anti-HBc total alone & 26 & 11.3 \\
Anti-HBc total + HBsAg & 07 & 3.0 \\
Anti-HBc total + Anti-HBs & 36 & 15.7 \\
Anti-HBs alone & 08 & 3.5 \\
No viral markers & 153 & 66.5 \\
Total & 230 & 100.0 \\
\hline
\end{tabular}

Tables 2 and 3 show the associations between the variables related to patients with HSS and the anti-HBc total and/or HBsAg and anti-HCV markers after adjustment for age of univariate analysis. 
TABLE 2. Association of variables related to patients with the hepatosplenic form of schistosomiasis, according to positivity for anti-HBc total and/ or HBsAg

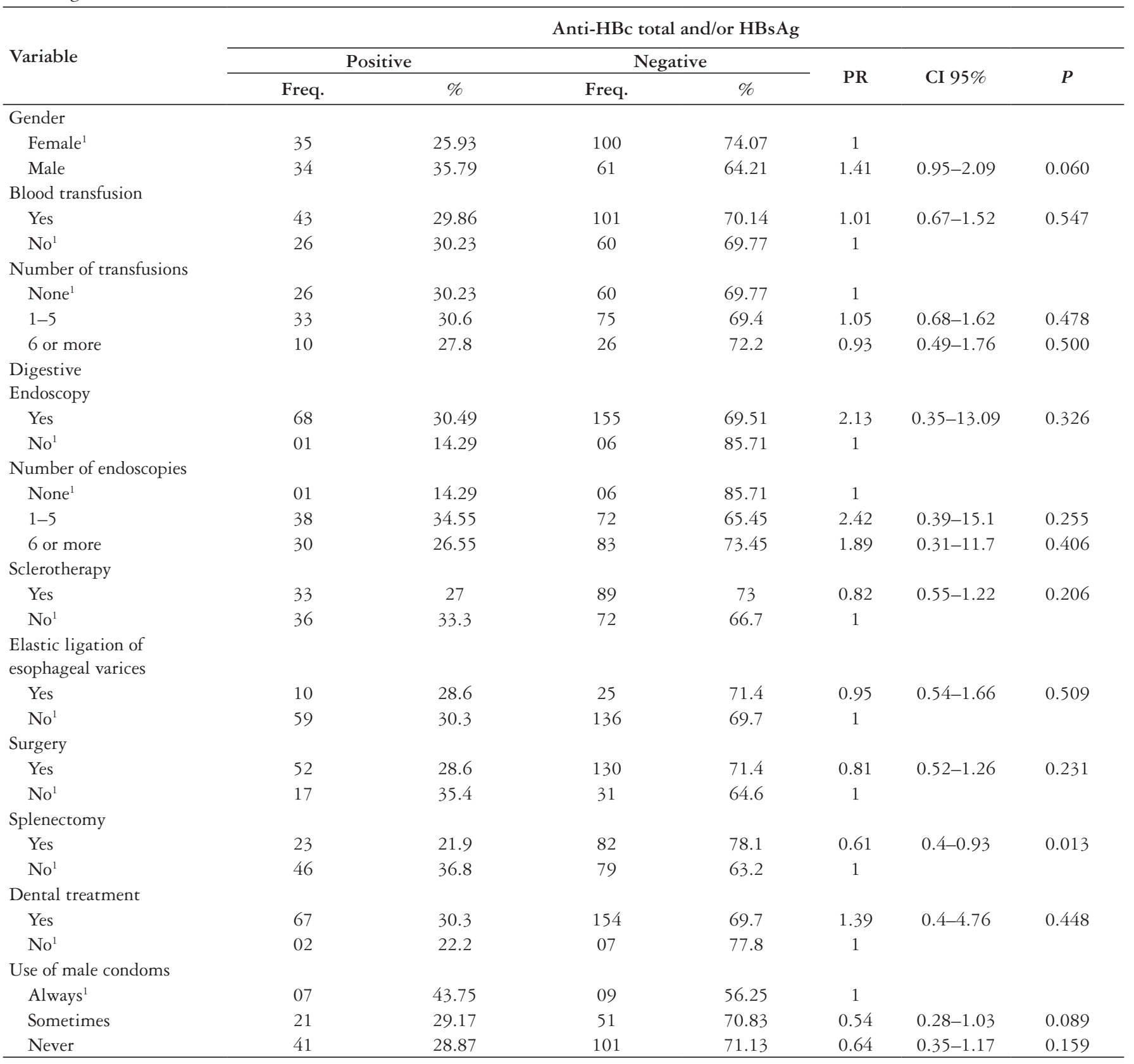

${ }^{1}$ Reference group; Freq.: frequency; PR: prevalence ratio 95\%; CI 95\%: confidence interval

Serological markers were more frequently observed in females, representing 50.7\% (35/69) and 58.8\% (10/17) of the total positive cases for $\mathrm{HBV}$ and $\mathrm{HCV}$, respectively. After adjusting for age, there was a greater probability for the presence of HBV markers in males, approaching statistical significance (Table 2).

To variable age, which was grouped by age group, there was higher frequency of patients $\geq 50$ years with positive serological markers of HBV (PR: 1.38; CI95\%: 0.81-2.11; $P$ $=0.337$ ) and HCV (PR: 2.95; CI95\%: 0.7-12.6; $P=0.162$ ), however this difference was no statistically significant.

A significant association was detected between the presence of anti-HCV and the receipt of six or more blood transfusions (Table 3).

There was no evidence of association between history and number of digestive endoscopies, history of sclerotherapy 
TABLE 3. Association of variables related to patients with the hepatosplenic form of schistosomiasis, according to positivity for anti-HCV

\begin{tabular}{|c|c|c|c|c|c|c|c|}
\hline \multirow{3}{*}{ Variable } & \multicolumn{7}{|c|}{ Anti-HCV } \\
\hline & \multicolumn{2}{|c|}{ Positive } & \multicolumn{2}{|c|}{ Negative } & \multirow{2}{*}{ PR } & \multirow{2}{*}{$95 \% \mathrm{CI}$} & \multirow{2}{*}{$P$} \\
\hline & Freq. & $\%$ & Freq. & $\%$ & & & \\
\hline \multicolumn{8}{|l|}{ Gender } \\
\hline Female $^{1}$ & 10 & 7.41 & 125 & 92.59 & 1 & & \\
\hline Male & 07 & 7.37 & 88 & 92.63 & 0.95 & $0.37-2.39$ & 0.550 \\
\hline \multicolumn{8}{|c|}{ Blood transfusion } \\
\hline Yes & 13 & 9.03 & 131 & 90.97 & 2.08 & $0.7-2.25$ & 0.134 \\
\hline $\mathrm{No}^{1}$ & 04 & 4.65 & 82 & 95.35 & 1 & & \\
\hline \multicolumn{8}{|c|}{ Number of transfusions } \\
\hline None $^{1}$ & 04 & 4.65 & 82 & 95.35 & 1 & & \\
\hline $1-5$ & 06 & 5.56 & 102 & 94.44 & 1.30 & $0.37-4.54$ & 0.467 \\
\hline 6 or more & 07 & 19.44 & 29 & 80.56 & 4.40 & $1.37-14.1$ & 0.012 \\
\hline \multicolumn{8}{|c|}{ Period of transfusion } \\
\hline None $^{1}$ & 04 & 4.65 & 82 & 95.35 & 1 & & \\
\hline Before 1993 & 09 & 12.9 & 61 & 87.1 & 2.76 & $0.89-8.7$ & 0.061 \\
\hline After 1993 & 04 & 5.4 & 70 & 94.6 & 1.47 & $0.69-5.56$ & 0.417 \\
\hline \multirow{2}{*}{\multicolumn{8}{|c|}{$\begin{array}{l}\text { Digestive } \\
\text { endoscopy }\end{array}$}} \\
\hline & & & & & & & \\
\hline Yes & 17 & 7.62 & 206 & 92.38 & -5 & & \\
\hline $\mathrm{No}^{1}$ & 00 & 00 & 07 & 100 & 1 & & \\
\hline \multicolumn{8}{|c|}{ Number of endoscopies } \\
\hline None $^{1}$ & 00 & 00 & 07 & 100 & 1 & & \\
\hline $1-5$ & 11 & 10 & 99 & 90 & -5 & & \\
\hline 6 or more & 06 & 5.31 & 107 & 94.69 & -5 & & \\
\hline \multicolumn{8}{|l|}{ Sclerotherapy } \\
\hline Yes & 8 & 6.6 & 114 & 93.4 & 0.83 & $0.33-2.06$ & 0.437 \\
\hline $\mathrm{No}^{1}$ & 9 & 8.3 & 99 & 91.7 & 1 & & \\
\hline \multicolumn{8}{|c|}{$\begin{array}{l}\text { Elastic ligation } \\
\text { of esophageal varices }\end{array}$} \\
\hline Yes & 1 & 2.9 & 34 & 97.1 & 0.35 & $0.05-2.53$ & 0.233 \\
\hline $\mathrm{No}^{1}$ & 16 & 8.2 & 179 & 91.8 & 1 & & \\
\hline \multicolumn{8}{|l|}{ Surgery } \\
\hline Yes & 15 & 8.24 & 167 & 91.76 & 2.0 & $0.48-8.42$ & 0.261 \\
\hline $\mathrm{No}^{1}$ & 02 & 4.17 & 46 & 95.83 & 1 & & \\
\hline \multicolumn{8}{|l|}{ Splenectomy } \\
\hline Yes & 9 & 8.6 & 96 & 91.4 & 1.44 & $0.58-3.58$ & 0.292 \\
\hline $\mathrm{No}^{1}$ & 8 & 6.4 & 117 & 93.6 & 1 & & \\
\hline \multicolumn{8}{|c|}{ Dental treatment } \\
\hline Yes & 17 & 7.7 & 204 & 92.3 & -5 & & \\
\hline $\mathrm{No}^{1}$ & 00 & 0 & 09 & 100 & 1 & & \\
\hline
\end{tabular}

${ }^{1}$ Reference group. Freq.: frequency; PR: prevalence ratio 95\%; CI 95\%: confidence interval; PR undefined

or elastic ligation of esophageal varices. An association was identified between the history of splenectomy and the detection of anti-HBc total and/or HBsAg markers (Table 2).

Among the seropositives for $\mathrm{HBV}$ or $\mathrm{HCV}$, there was not found history of intravenous drug use or the presence of tattoos and/or piercing. Only two patients were identified with a history of intercourse with other men, one was positive for anti-HBc total alone and the other one was positive for anti-HBc total and anti-HBs markers.
The variables gender, age and history of splenectomy demonstrated a significance probability below $20 \%(P<0.20)$ in univariate analysis for HBV, were included in a multiple logistic regression type forward. After multivariate analysis, only a history of splenectomy remained as a protective factor for the presence of anti-HBc total and/or HBsAg (Odds Ratio $=0.49$, $95 \%$ CI: $0.27-0.89, P=0.020)$. Additionally, serological markers for both viruses were simultaneously identified in eight patients, revealing a prevalence of $3.5 \%$ for $\mathrm{HBV} / \mathrm{HCV}$ coinfection. 


\section{DISCUSSION}

Compared to other Brazilians studies of patients with $\mathrm{HSS}$, the $30 \%$ prevalence of anti-HBc total and/or HBsAg was higher in this study, whereas the $7.4 \%$ prevalence of anti-HCV was lower ${ }^{(2,7,23,30)}$.

The prevalence of HBV and HCV serological markers in schistosomiasis patients ranging over according to origin of the patients involved and the endemic nature of parasitosis in the region evaluated.

Fieldwork studies detected a lower prevalence of these markers than identified in this report ${ }^{29,32)}$ because the frequency of HSS is reduced, even in endemic areas, and ranges from $2 \%-7 \% \%^{(3)}$. Furthermore, these individuals are less exposed to the risk of $\mathrm{HBV}$ and $\mathrm{HCV}$ transmission since they are less likely to undergo diagnostic (digestive endoscopy) or therapeutic (blood transfusions) procedures than outpatients or hospitalized patients.

The high prevalence of these markers in Egyptian studies is due the parenteral treatment of schistosomiasis with reuse of inadequately sterilized syringes during the decades from 1920 to 1980 , which is considered the main risk factor in this country ${ }^{(12)}$.

The presence of anti-HBc total alone in $11.3 \%$ of patients can be explained by false-positive reactions, the immunological window, late immunity expression (when the levels of antiHBs decay below the limit of detection of the serological tests and anti-HBc remains positive) or the persistence of chronic infection ${ }^{(11)}$

Anti-HBc positivity can occur concomitantly with low HBV viral load during a chronic infection when HBsAg is not detected by serological methods. These cases could suggest an occult $\mathrm{HBV}$ infection ${ }^{(25)}$. In this situation, only the polymerase chain reaction (PCR), which that detects viral genetic material, would elucidate the clinical condition of these individuals.

Regarding the low frequency of anti-HBs alone, the characteristic marker of vaccine response, we observed that part of the analyzed population came from country cities and belonged to a low social class that do not receive an $\mathrm{HBV}$ vaccination as routine practice. It is noteworthy that in the Reference Centers for Immunobiology Specials, the Brazilian Ministry of Health provides the HBV vaccine for patients with anatomical or functional asplenia and related diseases, among other indications, through the National Immunization Program.

Therefore, it would be recommend the serological screening and vaccination to the susceptible patients. Additionally, the high prevalence of HBV serologic markers observed in this study may be influenced by the lack of condom use in males that were positive for these markers.

The high prevalence of the serological markers in females and in patients aged $\geq 50$ years reflects the profile of the patients attending at study site. However, other studies have identified a higher prevalence in men ${ }^{(22)}$ also above 50 years ${ }^{(2)}$.

Males are more likely to be exposed to schistosomiasis due to increased contact with potentially contaminated water, especially in occupational activities, such as agriculture ${ }^{(26)}$. The large number of cases in patients of an advanced age reflects the cumulative exposure to risk factors, such as blood transfusions and surgeries, possibly made in the period before the inclusion of serological screening for $\mathrm{HBV}$ and $\mathrm{HCV}$ as obligatory hospital examinations.

The high frequency of blood transfusions among patients positive for the serological markers is in agreement with other studies ${ }^{(13,15)}$, which showed that blood transfusion is one of the most important risk factors for the transmission of $\mathrm{HBV}$ and $\mathrm{HCV}$.

Moreover, the number of transfusions received also represents an important risk factor for $\mathrm{HCV}$ infection, demonstrated by the significant association to the receipt of multiple transfusions. Likewise, the period in which the transfusions were received is important because before 1993 there was no serological screening for HCV in Brazil's blood banks. However, we did not observe an association with this variable because of the low frequency of anti-HCV in the study population.

The protective effect of splenectomy related to the presence of anti-HBc total and/or HBsAg was an unexpected finding. This procedure is considered of high complexity and requires a blood transfusion during surgery. In the majority of cases, it was probably executed in a period before the inclusion of serological screening for $\mathrm{HBV}$; thus we can admit the hypothesis of $\mathrm{HBV}$ transmission by blood transfusion in these patients.

Therefore, this association may be under the influence of a survival bias. Since hepatitis B is one of the major factors for the more severe clinic evolution of schistosomiasis, the infected patients may have died, causing a reduction in the number of splenectomized patients positive for HBV markers and affecting the association between the variables.

It is also possible to consider that, once having undergone splenectomy, these patients have been protected against future upper gastrointestinal bleeding, which minimized the chance of exposure to infection through blood transfusions.

There is controversy in the scientific literature with respect to the association between the history of digestive endoscopy and presence of serological and molecular markers for $\mathrm{HBV}$ and $\mathrm{HCV}$ in patients without schistosomiasis. Some case-control studies indicated a high risk of $\mathrm{HCV}$ transmission through endoscopy ${ }^{(9,16)}$, whereas prospective studies did not identify patients with seroconversion for $\mathrm{HBV}$ infection ${ }^{(20)}$, as observed for $\mathrm{HCV}^{(21)}$, after having undergone the procedure.

Due to the lack of patients without a history of digestive endoscopy and positive serology for $\mathrm{HCV}$ in this study, we were unable to establish a significant association with this variable. However, we identified an increased probability of the presence of anti-HBc total and/or HBsAg in patients who underwent endoscopy, although it was not statistically significant.

Viral transmission during endoscopy can be attributed to mistakes made during the cleaning and disinfection of the device. Studies have demonstrated the contamination of endoscopes after procedures in $\mathrm{HBV}^{(5)}$ and $\mathrm{HCV}$ positives ${ }^{(27)}$ patients. 
However, the viral genomes are eradicated when an effective device reprocessing is applied, as determined by $\operatorname{PCR}^{(4,14)}$.

We conclude that this study revealed the higher prevalence of serological markers of HBV and the lower prevalence of anti-HCV in patients with HSS. Our results indicate that females and patients of an advanced age are the most affected categories and patients that received multiple transfusions are at a higher probability of $\mathrm{HCV}$ infection.

\section{ACKNOWLEDGEMENTS}

The authors thank Research and Projects Financing (FINEP), the Outpatient Clinic of Gastroenterology at the Clinics Hospital, the Division of Virology at Laboratory of Immunopathology Keizo Asami and Ulysses Montarroyos for their help with the statistical analyses.

Silva JLA, Souza VSB, Vilella TAS, Domingues ALC, Coêlho MRCD. Marcadores sorológicos do VHB e VHC em pacientes com esquistossomose mansônica na forma hepatoesplênica. Arq Gastroenterol. 2011;48(2):124-30.

RESUMO - Contexto - A transfusão sanguínea destaca-se entre os fatores de risco implicados na transmissão dos vírus das hepatites B (VHB) e C (VHC); entretanto não há relatos da transmissão endoscópica destes vírus em pacientes com esquistossomose na forma hepatoesplênica. Objetivo Estimar a prevalência dos marcadores sorológicos do VHB e VHC em pacientes com esquistossomose hepatoesplênica e avaliar os possíveis fatores de risco associados a essas infecções. Métodos - Estudo do tipo transversal, com 230 pacientes com esquistossomose hepatoesplênica atendidos em um Hospital Universitário de Recife, PE, Brasil, no período de fevereiro a agosto de 2008. Os pacientes responderam a um questionário padronizado sobre os fatores de risco. Nas amostras de soro foram pesquisados o anti-HBc total, o anti-HBs, o HBsAg e o anti-VHC por ensaio imunoenzimático. As análises estatísticas utilizadas foram a univariada e a regressão logística múltipla. Resultados - Encontrou-se prevalência de $30 \%$ para anti-HBc total e/ou HBsAg e 7,4\% para o anti-VHC. Houve maior frequência de pacientes positivos do sexo feminino e idade $\geq 50$ anos para os marcadores analisados. Verificou-se associação significativa entre a presença do anti-HCV e a categoria de seis ou mais transfusões. Não foi constatada associação do antecedente e número de endoscopias digestivas com os marcadores sorológicos analisados. Conclusões - Constatou-se maior prevalência de marcadores sorológicos do VHB e menor prevalência para o anti-VHC. Evidenciou-se o sexo feminino e paciente de idade avançada como as categorias mais atingidas e maior probabilidade da infecção pelo VHC em pacientes politransfundidos.

DESCRITORES - Marcadores biológicos. Hepatite B. Hepatite C. Esquistossomose mansônica.

\section{REFERENCES}

1. Angelico M, Renganathan E, Gandin C, Fathy M, Profili MC, Refai W, De Santis A, Nagi A, Amin G, Capocaccia L, Callea F, Rapicetta M, Badr G, Rocchi G. Chronic liver disease in the Alexandria governorate, Egypt: contribution of schistosomiasis and hepatitis infections. J Hepatol. 1997;26:236-43.

2. Aquino RT, Chieffi PP, Catunda SM, Araújo MF, Ribeiro MC, Taddeo EF, Rolim EG. Hepatitis B and C virus markers among patients with hepatosplenic mansonic schistosomiasis. Rev Inst Med Trop São Paulo. 2000;42:313-20.

3. Barreto VST, Domingues ALC. Doença hepática na esquistossomose. In: Coelho J, editor:: Aparelho digestivo. Clínica e cirurgia. 2a ed. Rio de Janeiro: Medsi; 1996. p.1071-4

4. Bécheur H, Harzic M, Colardelle P, Deny P, Coste T, Dubeaux B, Chochon M, Roussin-Bretagne S, Doll J, Andrieu J. [Hepatitis C virus contamination of endoscopes and biopsy forceps]. Gastroenterol Clin Biol. 2000;24:906-10.

5. Bisset L, Cossart YE, Selby W, West R, Catterson D, O'Hara K, Vickery K. A prospective study of the efficacy of routine decontamination for gastrointestinal endoscopes and the risk factors for failure. Am J Infect Control. 2006;34:274-8.

6. Bronowicki JP, Venard V, Botté C, Monhoven N, Gastin I, Choné L, Hudziak H, Rhin B, Delanoë C, Lefaou A, Bigard MA, Gaucher P. Patient-to-patient transmission of hepatitis C virus during colonoscopy. N Engl J Med. 1997;337:237-40.

7. Conceição MJ, Argento CA, Chagas VL, Takiya CM, Moura DC, Silva SC. Prognosis of schistosomiasis mansoni patients infected with hepatitis B virus. Mem Inst Oswaldo Cruz. 1998;93:255-8.

8. Davis AR, Pink JM, Kowalik AM, Wylie BR, McCaughan GW. Multiple endoscopies in a Sydney blood donor found positive for hepatitis B and C antibodies. Med J Aust. 1996;164:571.

9. Delarocque-Astagneau E, Pillonel J, Valk H, Perra A, Laperche S, Desenclos JC. An incident case-control study of modes of hepatitis $\mathrm{C}$ virus transmission in France. Ann Epidemiol. 2007;17:755-62.

10. el-Sayed HF, Abaza SM, Mehanna S, Winch PJ. The prevalence of hepatitis $\mathrm{B}$ and $\mathrm{C}$ infections among immigrants to a newly reclaimed area endemic for
Schistosoma mansoni in Sinai, Egypt. Acta Trop. 1997;68:229-37.

11. Figueiredo JFC, Angerami RN. Aconselhamento a doadores e infecção oculta pelo VHB. Braz J Infect Dis. 2006;10:29-31.

12. Frank C, Mohamed MK, Strickland GT, Lavanchy D, Arthur RR, Magder LS, El Khoby T, Abdel-Wahab Y, Aly Ohn ES, Anwar W, Sallam I. The role of parenteral antischistosomal therapy in the spread of hepatitis C virus in Egypt. Lancet. 2000;355:887-91

13. Gad A, Tanaka E, Orii K, Rokuhara A, Nooman Z, Serwah AH, Shoair M, Yoshizawa K, Kiyosawa K. Relationship between hepatitis $\mathrm{C}$ virus infection and schistosomal liver disease: not simply an additive effect. J Gastroenterol. 2001;36:753-8

14. Ishino Y, Ido K, Sugano K. Contamination with hepatitis B virus DNA in gastrointestinal endoscope channels: risk of infection on reuse after on-site cleaning. Endoscopy. 2005;37:548-51.

15. Kamal S, Madwar M, Bianchi L, Tawil AE, Fawzy R, Peters T, Rasenack JW. Clinical, virological and histopathological features: long-term follow-up in patients with hepatitis C co-infected with $S$. mansoni. Liver. 2000;20:281-9.

16. Karmochkine M, Carrat F, Dos Santos O, Cacoub P, Raguin G. A case-control study of risk factors for hepatitis $\mathrm{C}$ infection in patients with unexplained routes of infection. J Viral Hepat. 2006;13:775-82.

17. Katz N, Peixoto SV. [Critical analysis of the estimated number of schistosomiasis mansoni carriers in Brazil]. Rev Soc Bras Med Trop. 2000;33:303-8.

18. Lacerda CM, Ramos H, Melo IS, Machado IS. Prevalência do anti-HCV e de marcadores do vírus B na esquistossomose hepatoesplênica. An Fac Med Univ Fed Pernamb. 1993;38:30-2.

19. Meira MRL, Figuerêdo-Silva J, Silveira MJC, Kelner S, Montenegro LT. Surgical hepatoesplênic schistosomiasis and hepatite B: a serological, histological and immunohistochemical study of 30 cases. An Fac Med Univ Fed Pernamb. 1999;44:77-81.

20. Mele A, Spada E, Saglioca L, Ragni P, Tosti ME, Gallo G, Moiraghi A, Balocchini E, Sangalli M, Lopalco PL, Stroffoli T. Risk of parenterally transmitted hepatitis following exposure to surgery or other invasive procedures: results from the hepatitis surveillance system in Italy. J Hepatol. 2001;35:284-9. 
21. Mikhail NN, Lewis DL, Omar N, Taha H, El-Badawy A, Abdel-Mawgoud N, Abdel-Hamid M, Strickland GT. Prospective study of cross-infection from upper-GI endoscopy in a hepatitis C-prevalent population. Gastrointest Endosc. 2007;65:584-8.

22. Mudawi HM, Simth HM, Fletcher IA, Fedail SS. Prevalence and common genotypes of $\mathrm{HCV}$ infection in Sudanese patients with hepatosplenic schistosomiasis. J Med Virol. 2007;79(9):1322-4.

23. Pereira LMMB, Spinelli V, Lacerda C, Mies S, Massarollo PCB, McFarlane LG. Hepatites B e C na Esquistossomose mansoni. GED Gastroenterol Endosc Dig. 2001;20:71-7.

24. Pordeus LC, Aguiar LR, Quinino LRM, Barbosa CS. A ocorrência das formas aguda e crônica da esquistossomose mansônica no Brasil no período de 1997 a 2006: uma revisão de literatura. Epidemiol Serv Saúde. 2008;17:163-75.

25. Raimondo G, Allain JP, Brunetto MR, Buendia MA, Chen DS, Colombo M, Craxì A, Donato F, Ferrari C, Gaeta GB, Gerlich WH, Levrero M, Locarnini S, Michalak T, Mondelli MU, Pawlotsky JM, Pollicino T, Prati D, Puoti M, Samuel D, Shouval D, Smedile A, Squadrito G, Trépo C, Villa E, Will H, Zanetti AR, Zoulim F. Statements from the Taormina expert meeting on occult hepatitis B virus infection. J Hepatol. 2008;49:652-7.

26. Resendes APC, Souza-Santos R, Barbosa CS. Internação hospitalar e mortalidade por esquistossomose mansônica no Estado de Pernambuco, Brasil, 1992/2000. Cad Saúde Pública. 2005;21:1392-401.
27. Sakai N, Tatsuta M, Iishi H, Yano H, Osaka S, Aoki A. Effectiveness of manual cleaning and disinfection of gastroendoscopes with $3 \%$ glutaraldehyde for decreasing the risk of transmission of hepatitis C virus. Am J Gastroenterol. 2001;96:1803-6.

28. Serufo JC, Lambertucci JR. Esquistossomose e hepatites virais: uma revisão. Rev Soc Bras Med Trop. 1997;30:313-22.

29. Serufo JC, Antunes CMF, Pinto-Silva RA, Gerspacher-Lara R, Rayes AAM Drummond SC, Reis CMF, Martins MJ, Mingoti SA, Lambertucci JR. Chronic carriers of hepatitis B surface antigen in an endemic area for Schistossomiasis mansoni in Brazil. Mem Inst Oswaldo Cruz. 1998;93(suppl. 1):249-53.

30. Silva JLA, Coêlho MRCD, Souza VSB, Domingues ALC. Soroprevalência de hepatite C em pacientes com esquistossomose. Rev Para Med. 2008;22:27-32.

31. Strickland GT, Elhefni H, Salman T, Waked I, Abdel-Hamid M, Mikhail NN, Esmat G, Fix A. Role of hepatitis $\mathrm{C}$ infection in chronic liver disease in Egypt. Am J Trop Med Hyg. 2002;67:436-42.

32. Tavares-Neto J, Prata A, Paraná R, Valente VB, Vitvitski L, Figueiredo JFC. Very low prevalence of hepatitis $\mathrm{C}$ virus infection in rural communities of Northeastern Brazil with a high prevalence of Schistosoma mansoni. Rev Soc Bras Med Trop. 2005;38:290-3.

Received 13/9/2010

Accepted 12/1/2011 